\title{
Effect of Fire on DNA and its profiling in homicide
}

\section{cases}

\begin{abstract}
In forensic investigation, experts deal with distinct types of crime scenes. Every crime scene is considered ubiquitous in correspondence of evidences including sexual assault, murder, homicide by adopting various methods i.e. burning, drowning etc. In homicidal cases, where dead bodies are burnt with very frequent and specific aspiration to dismantle the evidences and concealment the identity of the deceased. Insight of cases, it becomes to determine the cause of death on the spot due to burning and the presence of soot. In addition of it, Isolation of DNA from the remnants of dead bodies or blood present on the partially burnt belongings i.e. clothes, body tissues etc. is a tedious process. By this time, no technical process exists that could deal with such samples that has confronted the elevated temperature during burn process. In this study, an attempt was done to determine the quantity and quality of DNA from body tissues and blood found on the spot with high amount of soot and effect elevated temperature due to burning and accurate DNA profiling in such cases. As a resultant of this study, it was observed that a part/piece of clothes or the biological material can help to identify the deceased on the basis of DNA profiling from the sample which were not in the direct contact of heat/elevated temperature.
\end{abstract}

Keywords: dead bodies, DNA profiling, burning, homicide, clothes etc
Volume 7 Issue 2 - 2019

\author{
Naresh Kumar,' Amit Chauhan, ${ }^{2}$ Ritika \\ Gupta,' Aanchal Maitray,' Dhruw Sharma,' \\ Shukla SK ${ }^{2}$ \\ 'Forensic Science Laboratory, Home Department, India \\ ${ }^{2}$ Amity Institute of Forensic Sciences, Amity University, India
}

Correspondence: Amit Chauhan, Amity Institute of Forensic Sciences, Amity University, Uttar Pradesh-Noida- I25, India, Tel +91-997/918173/9540067484,

Emailamit_chauhan777@yahoo.in

Received: January 22, 2019 | Published: March 26, 2019

\section{Introduction}

In the field of forensic science, advancement in the technology has taken over the traditional methods of in the investigation. Yet, the forensic experts play a vital role and considered the key of the investigation in any case. Crime scene experts are deputed to the scene of occurrence in many cases i.e. sexual assault, murder, homicidal etc. In case of burning, crime scene experts investigate the burn dead body in distinct conditions. ${ }^{1}$ Investigator visit the scene and collect the biological substantial's left over the crime scene because of every perpetrator always try to cover up the homicidal case and try to represent the fire as defect or some natural causes. ${ }^{2}$ As the information passes over to the police or people nearby that place, they use water (Very common source to control the fire) to control. In such conditions, the blood patterns do not affect by the fire if the temperature is about $40^{\circ} \mathrm{C}$ or less than of it. ${ }^{3}$ The tissues which are not in direct contact of fire can be collected from the crime scene for DNA profiling. The isolation can be performed from the samples like hairs, nail clipping teeth or bone. Moreover, scalp hair can also be used for this purpose if the head area was not in the direct contact of fire. Though the hardconnective tissues can protect the DNA for a long span even if the temperature exceeds than $100^{\circ} \mathrm{C}$. These tissues are frequently used to extract DNA of the sample. In this case, the collected substantial was declined to provide the appropriate information of DNA due to the direct contact with heat. During the analysis of this case, the effect of burning has also been observed.

\section{Background}

In this case, Police received a phone call around 5.50am on 27 September about the burning incident. When law enforcement agency approached the crime scene, only a few spots were present. During the investigation of the site, blood stains, ${ }^{4}$ soot were observed on the surface of the floor and carpet wrapped around the dead body. A partial burnt dead body of a male victim was found from there. Police and forensic expert lifted the following items- burnt pieces of underwear and mat, Pieces of cemented floor having blood,2 burnt piece of mattress (plastic sheet), Blood spots with soot lifted with the wet cotton, Rusty metallic weapon of offence (Farsa- a sharp edge weapon), Clothes of accused persons, Blood gauze of deceased, Burnt hair and clothes of deceased. All the samples along with the items were collected by the police officer and preserved in the porous container/ as per protocol of BFS protocol to avoid degradation. ${ }^{5}$ At the time of sample collection, contamination of soil particles was avoided during the collection of samples as humic acid is inhibitors. ${ }^{6}$ During the disclosure of this case, it was convicted by the accused that the murder was committed by strangulation and later on the body was chopped. After two days of death, perpetrator failed to decompose the dead body that's why they burnt it with the help of kerosene oil. It is widely belief that DNA sample isolated from the blood lifted from the firefighting places can be problematic due certain causes i.e. high temperature, use of water, soot present on the blood spots and kerosene present on the blood-stained surfaces. At the scene of occurrence, it was very difficult to locate the pattern of blood stains. Therefore, the presence of blood was performed by the Benzidine test. Blood stained area of surface was also collected for the purpose of allocating the place of offence Blood stain pattern were also photographed with the camera along with the help of scale. The utilization of tripod is considered the best way to photograph the blood pattern and crime scene. ${ }^{7}$ During this investigation, it was also observed that the tongue of victim was protruding between the teeth while Eyes were partially opened and protruding. Reddish brown linear abrasion was present over front and right side of the neck, which was placed horizontally $2 \mathrm{~cm}$. in diameter and the right side of the neck; it was $1.5 \mathrm{~cm}$. in length. During the post mortem, a head injury was also observed as after the strangulation; the dead of the body was attacked by metallic weapon farsa. After postmortem, the cause of death was ascertained strangulation.

\section{Materials \& methods}

\section{DNA extraction}

All the samples of this case were sent to the Forensic Science laboratory by the investigation agency for DNA isolation and samples 
were preserved in the laboratory at $4^{\circ} \mathrm{C}$ to diminish the level of degradation. Samples, that were taken into small pieces were kept in $1.5 \mathrm{ml}$ tube and forensic buffer was added as per the protocol of automate extraction. Automate extraction is considered better technique for degraded samples or such sample that has faced elevated temperature of fire, were handled by magnetic based the auto mate extraction kit applied Biosystems and isolated as per manufacturer protocol. ${ }^{8}$ The organic extraction is not suitable in case of tissues and degraded sample.

\section{Quantitation}

After isolation, all the samples were quantified by using Duo kit of applied biosystems to quantify the DNA. The Quantifiler ${ }^{\circledR}$ Duo DNA Quantification Kit that enables forensic laboratories to simultaneously obtain a quantitative and qualitative assessment of total human male DNA in a single run. Highly sensitive real-time PCR reaction and inhibition in the samples. Autonomal STRs were amplified using AmPf1STR@ Identifiler TM PCR amplification kit (Applied Biosystems) according to kits. Amplified products were subjected to ABI 3500xl genetic analyzer.

\section{Results \& discussion}

As per the resultant of this study, the yield of DNA was significantly higher for all the samples that were not in direct contact of fire. A few materials that were found on cemented material was directly used for DNA isolation. It had given the lowest value in RT-PCR. From all the analysed samples, It was also observed that the DNA profile was full and accurate in the samples whereas in some samples DNA profile was partial while some of them; the alleles were found missing. The quantity of DNA was $0.04 \mathrm{ng}$ in partially burnt clothes while it was maximum from the sample of hair which was intact. The effect of fire had not only affected the quantity of DNA in the sample but also effected the accurate DNA profiling (Table 1).

As a resultant of this study, STR profiles were analyzed for all the samples and studied. In all the samples, STR profiles that were devoid of PCR artefacts and removal of inhibitor were found effective in isolating the high-quality genomic DNA. From the results, it was also observed that samples have given the minimum amount of DNA recovered from the samples as the concentration of soil material were higher that's why only a few of the samples were able to generate the proper profile otherwise it has given the of samples for DNA examination. It is very important to obtain appropriate quality \& quantity of DNA for identification from the putrefied and unidentified dead bodies. The presence of multiple peaks and imbalance of peak height was noticed due the impact of fire. The study suggests that direct fire affected area of cloth or body tissue should not be taken for DNA analysis. The soot does not affect the DNA profiling hence such area may be used for DNA profiling. In case of deep burning the hard material like bone or teeth may be used for the purpose of DNA. Figure 1- Figure 8 has shown the peak missing in some of the markers due to heat effect. The obtained graphical presentations are given below.

Table I Chart showing total DNA yield in $\eta g / \mu l$ obtained from different samples.

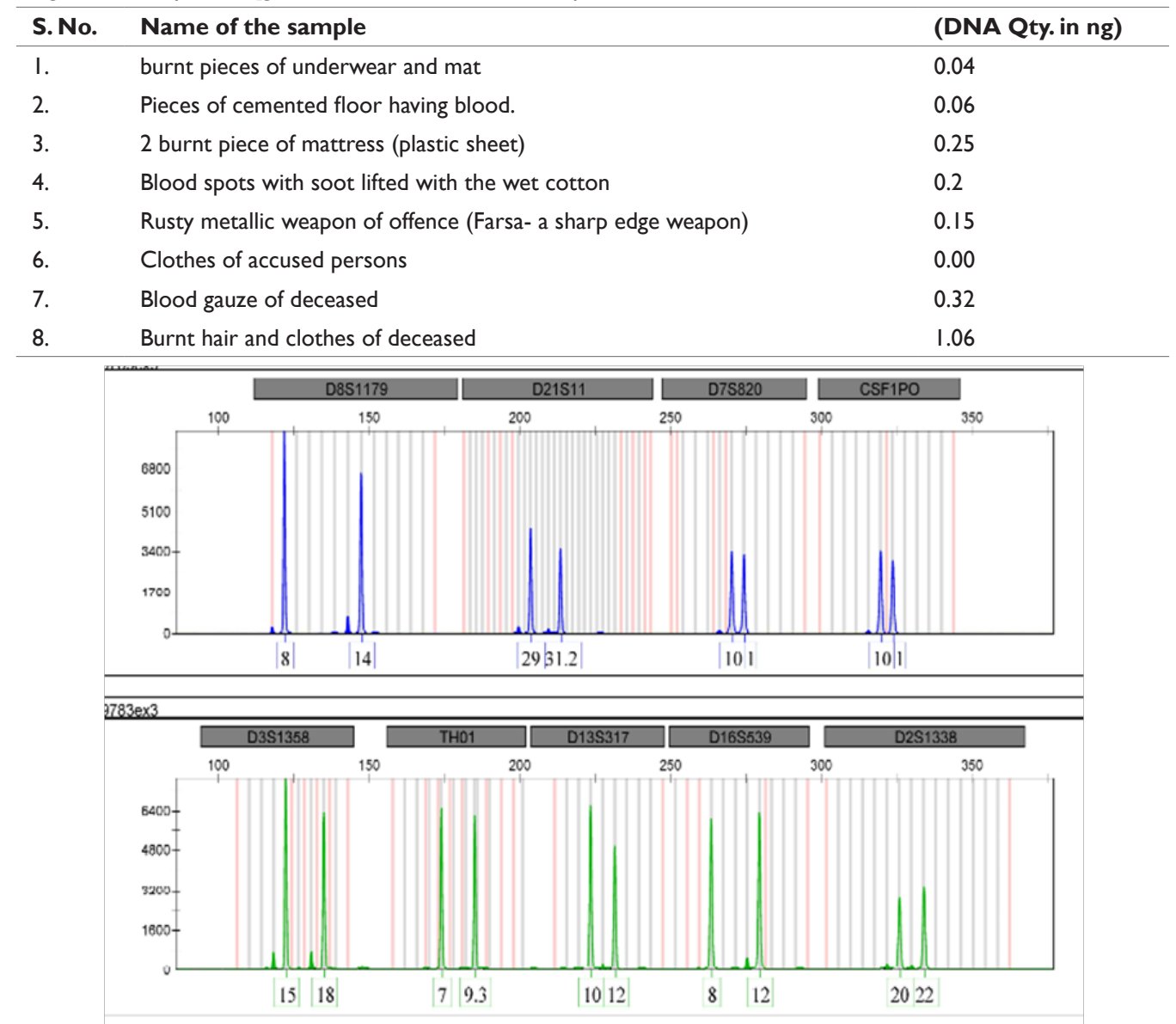

Figure I Profile of the sample not in direct contact of fire. 


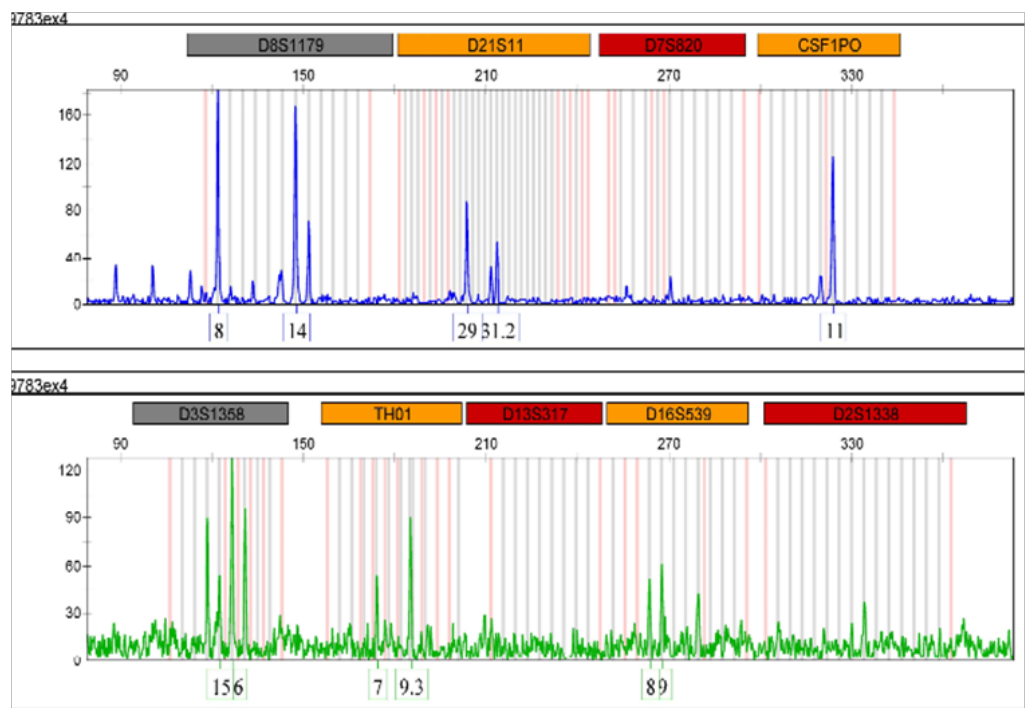

Figure 2 Direct effect of fire on the samples.

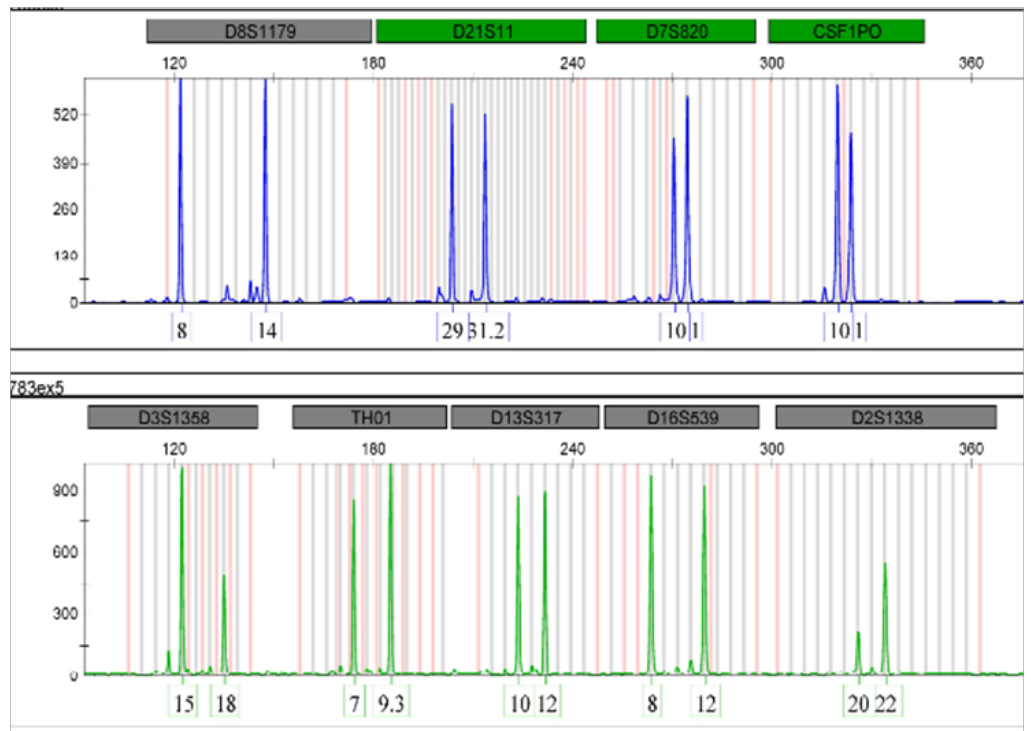

Figure 3 Partially burnt cloth profile.

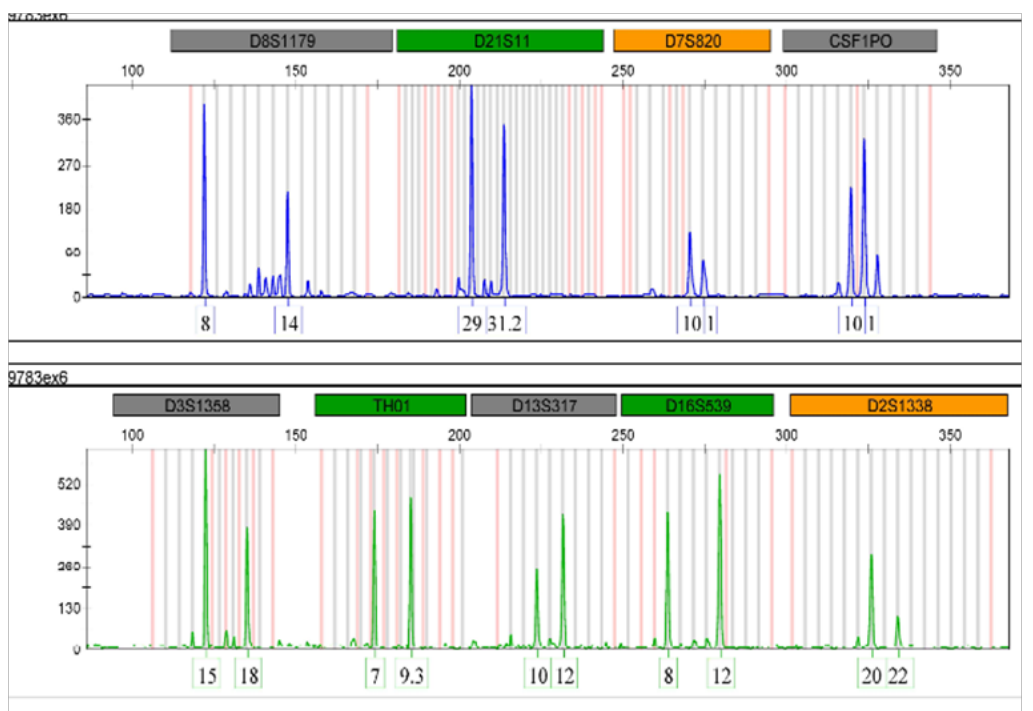

Figure 4 Profile from the partially burnt tissue.

Citation: Kumar N, Chauhan A, Gupta R, et al. Effect of Fire on DNA and its profiling in homicide cases. Forensic Res Criminol Int J. 20I 9;7(2):90-94. DOI: 


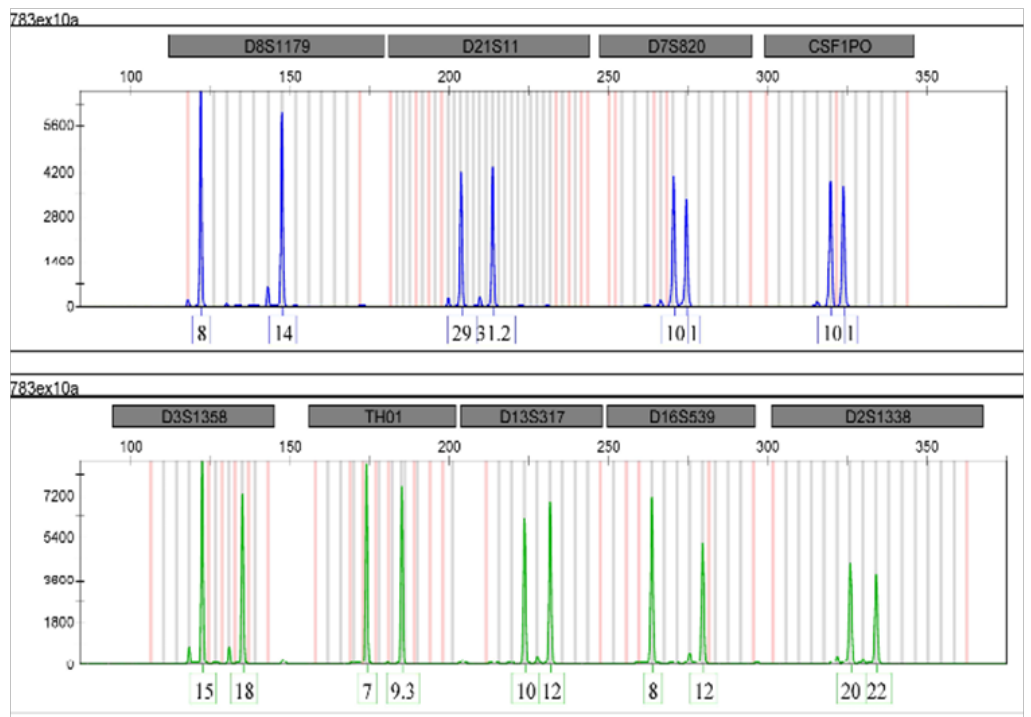

Figure 5 Profile generated from the blood taken from the smooth surface not contact of the fire.

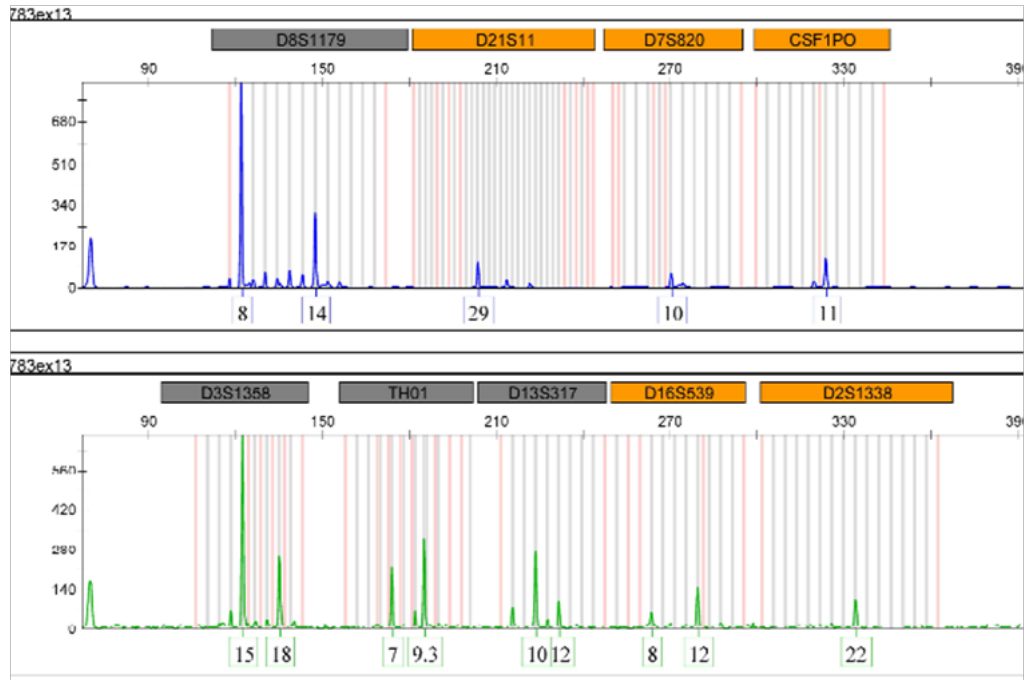

Figure 6 Profile generated from burnt banian.
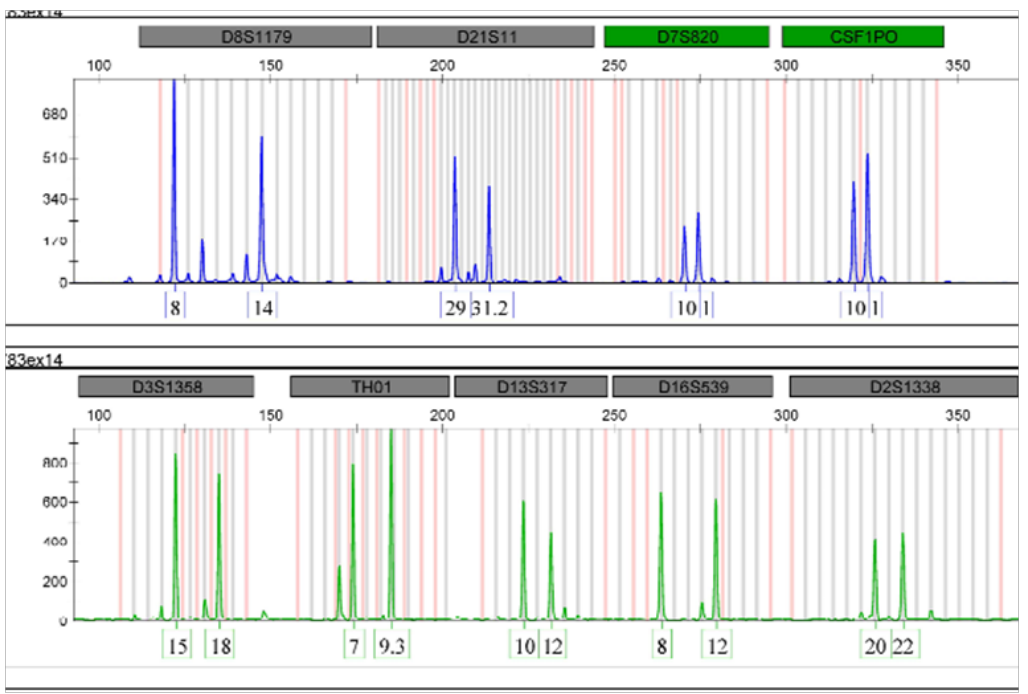

Figure 7 Profile from the hair root sample. 


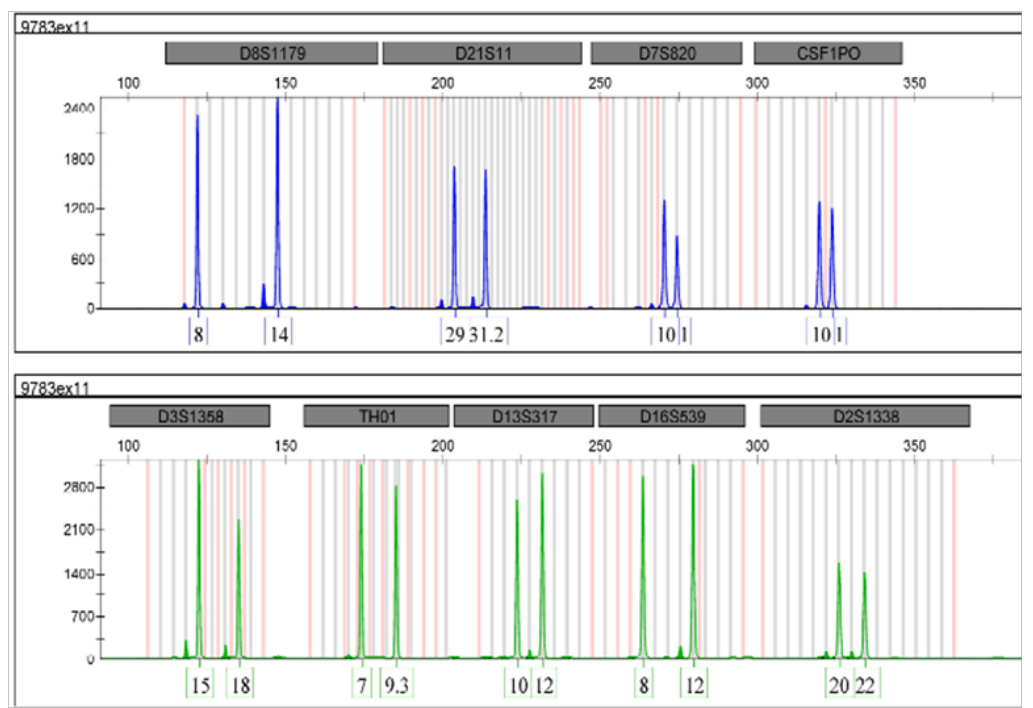

Figure 8 Profile generated from the blood gauze of deceased.

\section{Conclusion}

In forensic science, it is a compulsion to establish the identity of the victim from the distinct types of evidences/ruminants. To analyse the blood traces can often provide the significant reconstructive trail of evidences. Most often perpetrators deliberately set fires to destroy the evidences that can provide the identity of suspect. These types of valuable evidences provide link between the culprit and the victim. DNA has proved its value in the identification of unidentified dead bodies or from the burnt cases. According to the existing literature review for effect of fire on DNA and extreme heat on blood, blood in form of prime source of DNA are believed to be no longer traceable after exposure to a temperature of $1000^{\circ} \mathrm{C}$. It is an obvious fact the DNA profile is accurate to prove the identity of the victim from the remain ants that were directed towards the fire. It is very important to obtain appropriate quality \& quantity of DNA for identification from the putrefied and unidentified dead bodies. STR profiles that were devoid of PCR artefacts and removal of inhibitor were found effective in isolating the high-quality genomic DNA. Now a day, the use of DNA to identify the victim from the human remains after an accidental/deliberately fire, arson fire or mass disaster has become a standard technique in the scientific community.

\section{Source of funding}

NA

\section{Ethical clearance}

Not required.

\section{Acknowledgments}

None.

\section{Conflicts of interest}

The author declares that there are no conflicts of interest.

\section{References}

1. Chisum TBE. Crime Reconstruction. Elsevier Academic Press. 2007;1.

2. Geberth VJ. Practical homicide investigation tactics, procedures and forensic techniques. CRC Press. 1996;3.

3. Brady T, Tigmo John, Grant Graham S. Extreme temperature effects on bloodstain. IABPA News. 2002;18(3):3-20.

4. Bevel T. Bloodstain pattern analysis. CRC Press. 2002;2.

5. Zweidinger RA, Lytle L, Pitt C. Photography of bloodstains visualized by luminol. J Forensic Sci. 1973;18(4):296-300.

6. Tsai LY. Detection of low number of bacterial cells in soils and sediments by polymerase chain reaction. Appl Environmental microbiology. 1992;58(2):754-757.

7. Meyer HJ. The Kaprun cable car fire disaster-aspects of forensic organisation following a mass fatality with 155 victims. Forensic Sci Int. 2003;138(1-3):1-7.

8. Butler JM. Frensic DNA typing, biology, technology, and genetics of STR markers, $2^{\text {nd }}$ Edition. Elsvier Acedemic Press. 2005. 